\title{
Role of Interleukin-10-Expressing B Cells on the Pathophysiology of Chronic Sinusitis
}

\author{
Hee Sung Park ${ }^{1}$, Soo Kyoung Park ${ }^{1}$, Sun Hee Yeon ${ }^{1}$, Jun Xu ${ }^{1,2}$, Ki Sang Rha ${ }^{1}$, and Yong Min Kim ${ }^{1}$ \\ ${ }^{1}$ Department of Otorhinolaryngology-Head and Neck Surgery, Research Institute of Medical Science, Chungnam National University \\ School of Medicine, Daejeon, Korea \\ ${ }^{2}$ Department of Otorhinolaryngology-Head and Neck Surgery, Yanbian University Hospital, Yanji, China
}

\section{Interleukin-10 발현 B 세포가 만성 비부비동염의 병태생리에 미치는 영향}

박희성 ${ }^{1} \cdot$ 박수경 $^{1}$ 연선희 $\cdot \mathrm{Jun}^{\mathrm{Xu}^{1,2}} \cdot$ 나기상 $^{1} \cdot$ 김용민 $^{1}$

충남대학교 의과대학 의학전문대학원, 의학연구소, 이비인후과학교실, ${ }^{1}$ 연변대학교병원 이비인후과학교실 ${ }^{2}$

\author{
Received December 11, 2017 \\ Revised February 8, 2018 \\ Accepted February 13, 2018 \\ Address for correspondence \\ Yong Min Kim, MD \\ Department of Otorhinolaryngology- \\ Head and Neck Surgery, \\ Research Institute \\ of Medical Science, \\ Chungnam National University \\ School of Medicine, \\ 282 Munhwa-ro, Jung-gu, \\ Daejeon 35015, Korea \\ Tel $+82-42-280-7696$ \\ Fax $+82-42-253-4059$ \\ E-mail entkym@cnu.ac.kr
}

Background and Objectives Many kinds of inflammatory cells and cytokines are suggested to be related with pathophysiology of chronic rhinosinusitis with nasal polyp (CRSwNP), but its mechanism is not yet fully understood. In particular, little is known about the function and role of Interleukin-10 (IL-10) producing regulatory B cells. The aim of this study was to investigate the presence and function of B cells, especially IL-10-producing regulatory B cells, in the nasal polyp (NP) and nasal mucosa.

Subjects and Method Twenty patients with CRSwNP, 10 patients with chronic rhinosinusitis without nasal polyp (CRSsNP) and 10 control subjects were enrolled in this study. NP tissues and uncinate tissues were collected for analysis. Real-time polymerase chain reaction (RTPCR), immunohistochemistry were performed to measure the expression levels of the selected inflammatory cytokines and inflammation-associated molecules.

Results In the mucosal tissues of CRSsNP patients, the number of IL- $10^{+} \mathrm{B}$ cells was significantly lower than that of NP and control mucosa of CRSwNP patients. The number of IL-10 B cells was significantly increased in the eosinophilic NP, non-eosinohilic NP, CRSsNP, and control groups. There was a significant positive correlation between the number of IL- $10^{+} \mathrm{B}$ cells and B cell activating factor (BAFF).

Conclusion The expression of IL- $10^{+} \mathrm{B}$ cells and BAFF was significantly increased in CRSwNP patients compared to CRSsNP patients and control mucosal tissues, and IL- $10^{+} \mathrm{B}$ cells were more significantly increased in eosinophilic tissues. These results indicate that regulatory B cells are involved in the pathophysiology of eosinophilic NP and that BAFF contributes to the production of regulatory B cells. Korean J Otorhinolaryngol-Head Neck Surg 2018;61(8):412-20

Key Words B-lymphocytes · Interleukin-10 · Rhinitis · Sinusitis.

\section{서 론}

비용을 동반한 만성 비부비동염은 비폐색과 비루, 후각 감

This is an Open Access article distributed under the terms of the Creative Commons Attribution Non-Commercial License (https://creativecommons.org/licenses/by-nc/4.0) which permits unrestricted non-commercial use, distribution, and reproduction in any medium, provided the original work is properly cited.
퇴, 두통 등을 유발하여 삶의 질을 저하시키는 질환이다. 감 염 또는 비감염성 염증반응, 알레르기, 해부학적 이상 등이 주요 발병 인자로 생각되며, 감염 요인 중에는 곰팡이와 세 균이 만성적인 점막의 염증을 일으키는 데 중요한 역할을 하 는 것으로 알려져 있지만,2) 그 병태 생리와 병인에 대하여는 아직 정확히 밝혀져 있지 않다. 
비용은 다양한 $\mathrm{T}$ 세포의 활성화와 함께 조절 $\mathrm{T}$ 세포의 기 능 이상에 의해 발생하는 것으로 알려져 있는데, 서양인에서 는 Th2에 편향된 염증반응을 보이고, 동양인에서는 Th1/ Th17에 보다 더 편향된 염증반응이 보인다고 알려져 있다.,4) 특히, 최근에는 비용 조직에서 대조군 점막 조직에 비해 조절 $\mathrm{T}$ 세포의 기능이 떨어져 있거나 조절 세포에 중요한 전사 인 자인 FoxP3의 발현이 저하 되어 있음이 알려졌다.,6)

비용은 조직학적으로 상피세포, 섬유아세포, 혈관 세포 등 의 기질 세포와, 림프구, 과립구, 대식세포, 수지상세포 등의 다 양한 염증세포들로 구성되어 있다. ${ }^{7)}$ 이 중 B 세포는 다양한 항체를 생성하여 적응면역반응 중 체액성 면역을 담당할 뿐 만 아니라 항원 제시, 싸이토카인 생성, 림프 조직의 구성 등의 기능을 수행함으로써 면역반응을 일으키고, 증폭하는 역할 을 한다. ${ }^{89)} \mathrm{B}$ 세포의 수와 기능이 비정상적인 경우 천식과 알 레르기, 자가면역질환 등이 발생하고, 종양 억제 면역과 장기 이식 면역에서도 중요한 역할을 하는 것으로 잘 알려져 있 다. ${ }^{10,11)}$ 조절 $\mathrm{T}$ 세포와 비슷한 기능을 갖는 조절 $\mathrm{B}$ 세포의 존 재가 알려졌는데 특히, interleukin-10(IL-10)을 생성하는 B 세포에 의해 일어나는 IL-10 매개 면역반응이 과도한 면역반 응을 억제하는 데 중요하고, 실제 만성 염증성 질환과 자가면 역질환에서는 IL-10 생성 조절 B 세포의 수와 기능 이상이 질환의 병태생리와 관련이 있는 것으로 알려져 있다. ${ }^{12)} \mathrm{Jun}$ $\mathrm{Xu}$ 등은 만성 비부비동염 환자의 조직에서 $\mathrm{IL}-10$ 과 $\mathrm{B}$ 세포 의 표면 항원인 $\mathrm{CD} 19$ 이 통계적으로 유의한 양의 상관관계를 보인다고 보고한 바가 있지만 만성 비부비동염의 병태생리에 서 조절 B 세포, 특히 IL-10 생성 조절 B 세포의 기능과 역 할에 대한 것은 알려져 있지 않다.

IL-10은 Th2 세포, B 림프구, 각질 세포 등에서 분비되어 IL-1 $\beta$, IL-6, tumor necrosis factor- $\alpha(\mathrm{TNF}-\alpha)$, IL-8, mac-

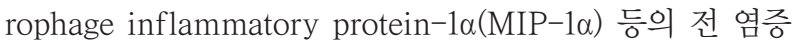
싸이토카인의 합성을 억제하여 염증반응을 하향 조절한다. ${ }^{13)}$ IL-10 Knock out 마우스를 이용한 연구에서 IL-10은 장에 서 염증반응을 억제하는 데 필수적인 면역조절제 기능을 한 다고 알려져 있으며, ${ }^{14)}$ 실제로 크론병 환자에서 IL-10 생성 박테리아를 이용한 치료로 과도한 면역반응을 중재하였다는 연구도 있다. ${ }^{15)}$ Lee 등 ${ }^{16)}$ 은 급성 중이염 동물 모델의 중이강 내에 IL-10을 주입함으로써 염증반응을 억제하는 효과를 보 였다고 보고하였지만, 만성 부비동염에서 $\mathrm{IL}-10$ 의 기능과 역 할을 규명하는 연구는 아직까지 상대적으로 드물다. 그동안 많은 연구들이 비용의 병태생리를 밝히기 위해 진행되어 왔 지만 B 세포 관련 연구는 그 수가 적고 특히, IL-10 생성 조 절 $\mathrm{B}$ 세포에 관련된 연구는 전무한 실정이다. 따라서 본 연 구에서는 비용을 동반한 만성 비부비동염 환자의 비용을 조
직학적인 소견에 따라 호산구성, 비호산구성 비용으로 구분 하였고, 각 군에서 B 세포 특히 IL-10을 생성하는 조절 B 세 포의 비용 조직과 비점막에서의 존재 여부와 기능을 규명하 고자 하였다.

\section{대상 및 방법}

\section{대 상}

본 연구는 2016년 3월부터 2017년 3월까지 대학교병원에서 수술을 시행한 12 세 이상, 80 세 미만의 환자 40명을 대상으 로 하였다. 이 중 비용을 동반한 만성 비부비동염군(chronic rhinosinusitis with nasal polyp, CRSwNP)이 20명, 비용을 동반하지 않은 만성 비부비동염군(chronic rhinosinusitis without nasal polyp, CRSsNP)이 10명, 대조군(control)이 10 명이었다. 대조군은 안와골절, 비누낭 폐쇄증으로 안과 수 술을 받은 환자를 대상으로 하였다. 본 연구는 저자들이 속한 기관의 임상연구심의 위원회(Institutional Review Board)의 연구 승인(IRB No. 2015-05-040)하에 전향적으로 이루어졌 으며 환자에 대한 임상적 정보는 의무기록을 후향적으로 분 석하였다. 모든 환자로부터 수술 전 동의서를 받아 연구에 동 의한 환자만을 실험대상에 포함 시켰다. 대조군 및 CRSsNP 군에서는 구상돌기 점막 조직을 채취하였으며 CRSwNP 군 에서는 구상돌기 점막과 비용을 같이 채취하였다.

만성 비부비동염의 진단은 환자의 증상, 내시경 검사, 부비 동 전산화단층촬영(computed tomography, $\mathrm{CT}$ )에 근거하여 European position paper on rhinosinusitis and NPs 2012 $(\operatorname{EPOS} 2012)^{17)}$ 에 포함된 부비동 진단의 가이드라인에 따라 이루어졌다. 수술 전 4주 이내에 전신 또는 국소 코르티코스 테로이드, 항생제, 항염증제(antileukotriens)를 복용한 환자, 상기도 감염이 있었던 환자, 재수술 환자, 자가면역질환 등의 전신질환이 있는 환자는 연구에서 제외하였다. 비부비동염의 침범 범위는 Lund-Mackay CT score에 따라 각 부비동에 혼 탁이 없는 경우는 0 점, 부분적인 혼탁은 1점, 전반적인 혼탁은 2점으로 평가하였고 양측의 점수를 합하여 평가하였다.

채취한 비용 및 구상돌기 조직은 hematoxylin and eosin 염색을 하여 점막에 침윤된 호산구 수가 전체 염증세포 중 $10 \%$ 이상인 경우를 호산구성 비용(eocinophilic nasal polyp, $\mathrm{e}-\mathrm{NP}$ )으로, $10 \%$ 미만인 경우를 비호산구성 비용(non-eosinophilic nasal polyp, n-NP)으로 분류하였다. 20명의 CRSwNP 군 환자 중 호산구성 비용이 10명, 비호산구성 비용이 10명이 었다(Table 1). 


\section{방 법}

\section{이중 면역조직형광염색}

$10 \%$ 중성 포르말린 고정과 파라핀 포매를 거친 조직을 $3 \mu \mathrm{m}$ 두께로 연속 절편을 만들어 조직 슬라이드를 만들었다. 조직 슬라이드는 $100 \%$ xylen에 탈파라핀화 하고, 무수알코올 $90 \%$, $75 \%$ 및 50\% 에탄올에 각각 2분씩 처리하여 함수 시켰다. 내 인성 과산화효소의 활성을 억제하기 위해 $3 \%$ 과산화수소에 10 분간 처리하고 증류수로 세척한 다음 $50 \mathrm{mM}$ Tris 완충용 액(Tris-buffered saline, pH 7.5)으로 수세하였다. 비특이적 단백접착반응을 제거하기 위해 $10 \%$ bovine serum albumin 에 1 시간 동안 반응시켰다. 일차 항체인 human-IL-10에 대 한 rat monoclonal antibody(Abcam, Cambridge, MA, USA)를 Tris 완충 용액에 1:200으로 희석하여 $4^{\circ} \mathrm{C}$ 에서 하루 밤 동안 반응시켰다. Phosphate-buffered saline(PBS)로 세 차 례 세척 후 이차 항체인 Cy3-biotin Rb(red)(GE Healthcare, Tokyo, Japan)를 융합시킨 후 2시간 동안 반응시켰다. Human$\mathrm{CD} 20$ 에 대해서는 mouse monoclonal antibody(BD Biosciences, San Jose, CA, USA)를 사용하였다. CD20의 경우 Cy2streptoavidin(green)(GE Healthcare)을 융합시켜 관찰하였 다. PBS washing 후 4', 6'-diamidino-2-phenlylindole, dihydrochloride(DAPI, Santa Cruz biotechnology, Santa Cruz, $\mathrm{CA}, \mathrm{USA}$ )로 핵 염색을 하였다.

면역조직형광염색을 마친 슬라이드는 형광 현미경(Olympus, Tokyo, Japan)을 이용하여 400배 배율로 무작위로 3곳을 선 정하여 관찰하였다. $\mathrm{IL}-10$ 과 $\mathrm{CD} 20$ 발현 세포 수를 각각 측 정하였고 둘 모두 발현하는 세포의 수를 측정하였다. 면역형 광염색결과 판독은 환자의 임상 정보를 모르는 2 명의 병리 과 의사에 의하여 이루어졌다.

Real time fluorescence quantitative polymerase chain reaction

TRIzol $^{\circledR}$ 시약(Invitrogen, Carlsbad, CA, USA)을 이용하여 조직 샘플들로부터 총 RNA를 추출했다. $\mathrm{cDNA}$ 합성을 위해
AccuPower ${ }^{\circledR}$ RT PreMix(Bioneer, Daejeon, Republic of Ko$\mathrm{rea}$ )를 이용하여 총 RNA $1 \mu \mathrm{g}$ 을 전사하였다. $\mathrm{T} 100^{\mathrm{TM}}$ Thermal Cycler(Bio-Rad Laboratories, Hercules, CA, USA)를 이용하여 $\mathrm{cDNA}$ 합성을 위해 중합 효소 연쇄 반응을 수행하 였다. mRNA의 발현은 PowerUp ${ }^{\mathrm{TM}} \mathrm{SYBR}^{\circledR}$ Green Master Mix(Applied Biosystems, Carlsbad, CA, USA)를 사용하여 CFX Connect ${ }^{\mathrm{TM}}$ Real-Time Polymerase Chain Reaction Detection System(Bio-Rad Laboratories, Hercules, CA, USA)으로 분석하였다. 모든 polymerase chain reaction (PCR) 분석은 3회 수행하였고 각 표본에 대해 표적 분자와 글리세롤 알데히드 3-인산 탈수소 효소(GAPDH) $\left(\triangle \mathrm{Ct}_{\mathrm{target}}\right.$ gene, $\left.\Delta \mathrm{Ct}_{\text {reference gene }}\right)$ 사이의 임계 사이클의 차이를 결정한 후 보정된 델타 $\mathrm{Ct}$ 값 $\left(\Delta \Delta \mathrm{Ct}, \Delta \mathrm{Ct}_{\text {target gene }}-\Delta \mathrm{Ct}_{\text {reference gene }}\right)$ 을 계 산하였다. 이어서 상대 정량(real-time quantitative, $\mathrm{RQ}$ ) 값 을 $\mathrm{RQ}=2^{-\Delta \Delta \mathrm{Ct}}$ 방정식을 사용하여 계산하였다. $\mathrm{PCR}$ 은 GenoTech(GenoTech, Daejeon, Republic of Korea)에서 구입 한 자 체 설계 프라이머를 사용하였다. B cell activating factor(BAFF, sense sequence: TGCAGACAGTGAAACACCAAC and antisence sequence: GACATGGACCTTCTTCCTCTGA), IL-5(sense sequence: GGATGCTTCTGCATTTGAGTTT and antisence sequence: CAGTGCCAAGGTCTCTTTCA), IL-17A(sense sequence: CCCCATCCAGCAAGAGATCC and antisence sequence: CCCACGGACACCAGTATCTT), interferon $-\gamma($ IFN $-\gamma$ sense sequence: AGTGATGGCT GAACTGTCGC and antisence sequence: CTGGGATG CTCTTCGACCTC), IL-25(sense sequence: GTCATGGG AACCCACACCTA and antisence sequence: TGCTGTTG AGGGGTCCATCT), IL-33(sense sequence: CATGCCA ACAACAAGGAACA and antisence sequence: AGGACA AAGAAGGCCTGGTC), thymic stromal lymphopoietin (TSLP, sense sequence: TGCCTTAGCTATCTGGTGCC and antisence sequence: TTGAAGCGACGCCACAATCC), IL-10(sense sequence: GGCACCCAGTCTGAGAACAG and antisence sequence: ACTCTGCTGAAGGCATCTCG).

Table 1. Patient characteristics

\begin{tabular}{|c|c|c|c|c|c|}
\hline Group & Controls & CRSsNP & CRSWNP (e) & CRSWNP (n) & $p$ value \\
\hline Total of subjects (n) & 10 & 10 & 10 & 10 & \\
\hline Gender, male $(n, \%)$ & $8(80)$ & $8(80)$ & $8(80)$ & $7(7)$ & 0.638 \\
\hline Age, mean (year, range) & $34.1(20-66)$ & $45.6(23-67)$ & $49.9(26-63)$ & $51.6(12-76)$ & 0.435 \\
\hline Bronchial asthma (n, \%) & $0(0)$ & $1(8)$ & $3(30)$ & $2(20)$ & 0.821 \\
\hline Atopy (n, \%) & $0(0)$ & $0(0)$ & $1(10)$ & $0(0)$ & 1 \\
\hline Aspirin intolerence $(n, \%)$ & $0(0)$ & $0(0)$ & $0(0)$ & $0(0)$ & 0.463 \\
\hline Lund-Mackay CT score (mean) & - & 6.25 & 11.4 & 12.6 & \\
\hline
\end{tabular}

CRSsNP: chronic rhinosinusitis without nasal polyp, CRSWNP: chronic rhinosinusitis with nasal polyp, e: eosinophilic nasal polyp group, n: non-eosinophilic nasal polyp group, CT: computed tomography 


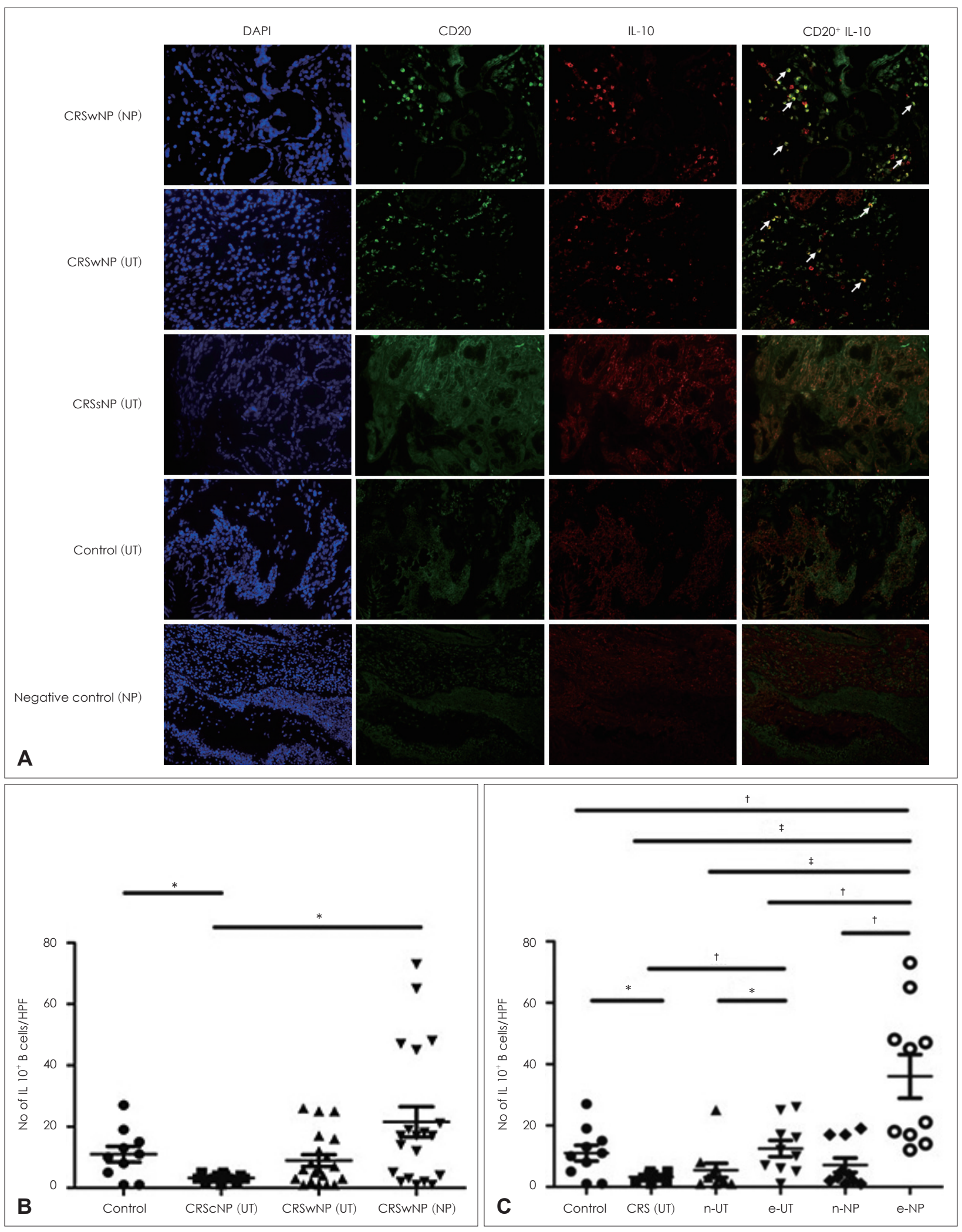

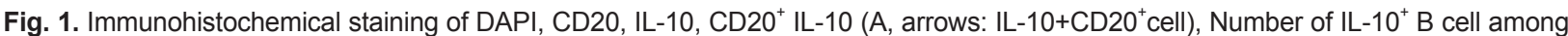
the groups. ${ }^{*} p<0.05,{ }^{\dagger} p<0.005,{ }^{\ddagger} p<0.0005$ (B and C). DAPI: 4', 6'-diamidino-2-phenlylindole, dihydrochloride, IL: interleukin, CRSwNP: chronic rhinosinusitis with nasal polyp, CRSsNP: chronic rhinosinusitis without nasal polyp, NP: nasal polyp, UT: uncinate, HPF: high power field, CRS: chronic rhinosinusitis, CRScNP: chronic rhinosinusitis without nasal polyp, n: non-eosinophilic nasal polyp group, e: eosinophilic nasal polyp group. 

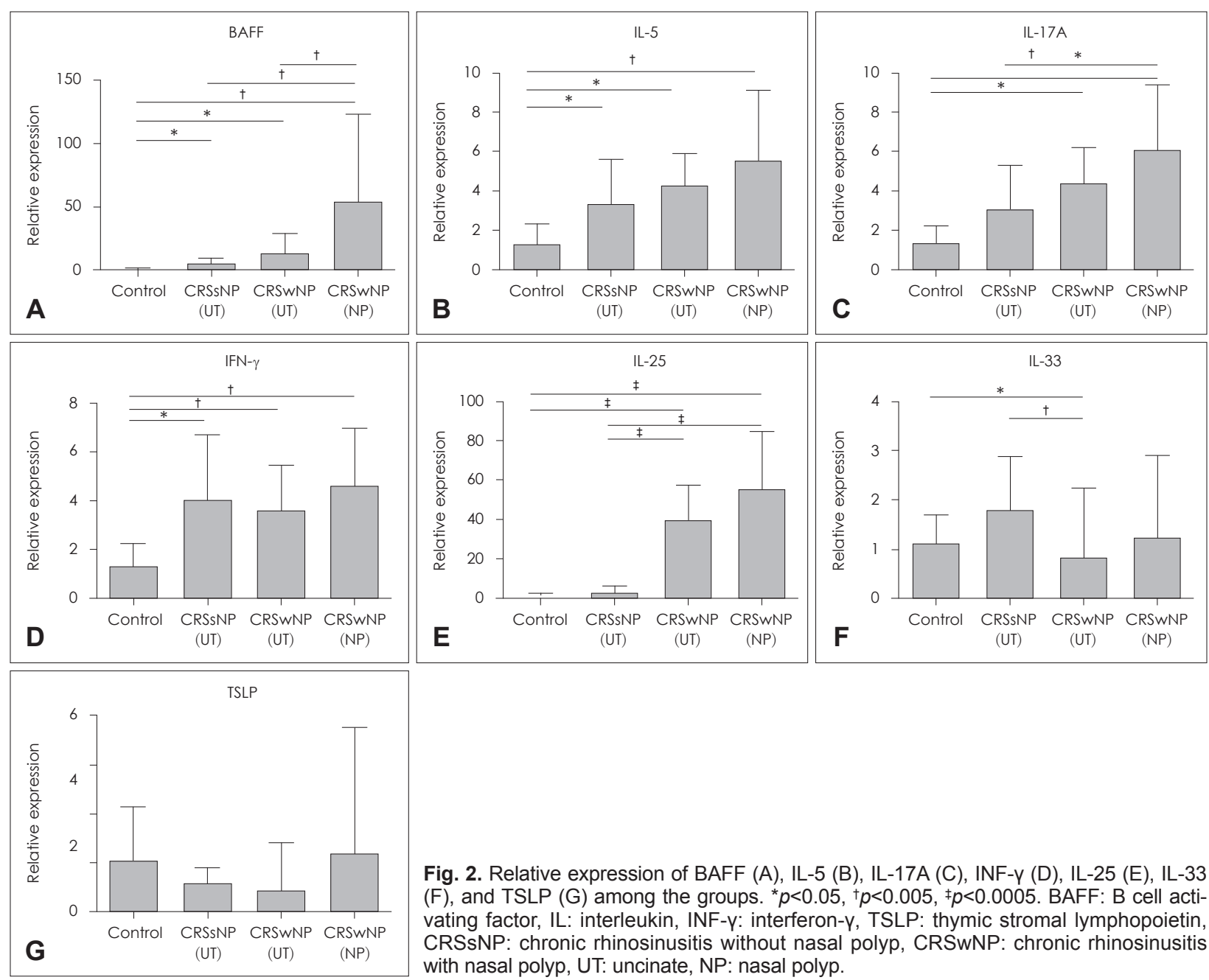

Fig. 2. Relative expression of BAFF (A), IL-5 (B), IL-17A (C), INF-y (D), IL-25 (E), IL-33 $(F)$, and TSLP (G) among the groups. ${ }^{*} p<0.05,{ }^{\dagger} p<0.005,{ }^{\ddagger} p<0.0005$. BAFF: B cell activating factor, IL: interleukin, INF- $\gamma$ : interferon- $\gamma$, TSLP: thymic stromal lymphopoietin, CRSsNP: chronic rhinosinusitis without nasal polyp, CRSwNP: chronic rhinosinusitis with nasal polyp, UT: uncinate, NP: nasal polyp.

\section{통계 분석}

SPSS(version 18.0, SPSS Inc., Chicago, IL, USA)와 GraphPad Prism 6(version 6.01, GraphPad Software, La Jolla, CA, USA)을 이용하여 통계 분석을 시행하였다. CD20, IL-10 양성 세포의 수를 one-way analysis of variance method 로 분석 후 Tukey method로 사후 분석을 하였다. 그룹 간의 차이는 Kruskal-Wallis tests를 사용하여 분석하였고 변수 관계를 결정하기 위해 Spearman correlation 검사를 하였다. 모든 결과값은 $p$ 값이 0.05 이하인 경우를 통계학적으로 유의 한 것으로 판정하였다.

\section{결 과}

총 40명 중 CRSwNP 군이 20명, CRSsNP 군이 10명, 대조 군이 10명이었다. CRSwNP 군은 남자가 15명, 여자가 5명이 었고, 연령 분포는 12 세에서 76 세까지로 평균연령은 50.75세 였다. CRSwNP 군은 e-NP 군이 10명, n-NP 군이 10명이었다.
CRS 군, e-NP 군, n-NP 군 간의 비교에서 Lund-Mackay CT score의 평균은 각각 $6.25,11.4,12.6$ 이었다. 각각의 환자 에서 bronchial asthma, atopy, aspirin intolerance(Table 1)

는 통계적으로 유의한 차이를 보이지 않았다.

\section{$\mathrm{IL}-10^{+} \mathrm{B}$ 세포의 발현}

촬영 위치에 따라 발현 정도의 차이가 관찰되었으나 무작 위로 촬영한 3곳을 종합적으로 평가해 보았을 때, $\mathrm{IL}-10$ 과 $\mathrm{CD} 20$ 모두 $\mathrm{CRSwNP}$ 군에서 그 발현이 증가하였고 둘 다

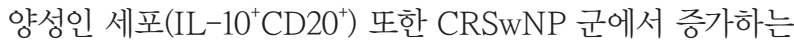
양상을 보였다. $\mathrm{CRSsNP}$ 군의 점막에서는 $\mathrm{CRSwNP}$ 군의 점 막뿐만 아니라 대조군 점막에 비해서도 $\mathrm{IL}-10^{+} \mathrm{B}$ 세포의 발 현이 감소하였다(Fig. $1 \mathrm{~A}$ and B). CRSwNP 군을 호산구성 비용과 비호산구성 비용으로 나누어 비교하였을 때에는 호 산구성 비용이 대조군과 CRSsNP 군의 구상돌기, 비호산구 성 비용 환자의 비용과 구상돌기, 호산구성 비용 환자의 구 상돌기에 비해 $\mathrm{IL}-10^{+} \mathrm{B}$ 세포의 수가 통계적으로 유의하게 
증가되어 있었다. 호산구성 비용 환자의 구상돌기에서도 비 호산구성 비용 환자와 CRSsNP 환자의 구상돌기와 비교하 였을 때 $\mathrm{IL}-10^{+} \mathrm{B}$ 세포의 발현이 유의하게 증가되어 있었다 (Fig. 1C).

\section{조직 내 싸이토카인의 발현}

각 군의 조직에서 싸이토카인(IL-5, IL-17A, IL-25, IL$33, \mathrm{TSLP}, \mathrm{INF}-\gamma, \mathrm{BAFF})$ 의 발현을 Real Time-PCR로 분 석하였다. BAFF는 CRSsNP 군과 대조군에 비해 CRSwNP 군에서 의미 있게 발현이 높았고, CRSwNP 군에서도 구상돌 기 조직에 비해 비용 조직에서 그 발현이 의미 있게 높았다. Th2 싸이토카인인 IL-5역시 CRSsNP 군과 대조군에 비해 CRSwNP 군에서 의미 있게 발현이 높았지만, 구상돌기와 비 용 사이에 의미 있는 발현의 차이는 보이지 않았다. Th17 싸 이토카인인 IL-17A도 CRSwNP 군이 CRSsNP 군과 대조군 에 비해 발현이 의미 있게 높았지만, CRSsNP 군과 CRSwNP 군의 구상돌기 조직에서는 그 발현이 의미 있는 차이는 없었 다. Th1 싸이토카인인 IFN- $\gamma$ 는 대조군에 비해 CRSwNP 군 과 $\mathrm{CRSsNP}$ 군 모두 그 발현이 의미 있게 높았지만, CRSwNP
군과 CRSsNP 군 사이에서는 의미 있는 차이를 보이지 않았 다. 선천성 싸이토카인(innate cytokine)으로 알려진 IL-25, $\mathrm{IL}-33$, TSLP는 각 군 사이에 발현이 서로 다르게 나타났다. 먼저 IL-25는 특이하게 CRSwNP 군에서만 다른 군들(대조 군과 CRSsNP 군)에 비해 의미 있게 높게 나타났고 발현의 차이도 크다는 것을 알 수 있었다. 그에 비해 IL-33은 오히려 CRSwNP 군의 구상돌기 조직에서 대조군과 CRSsNP 군에 비해 의미 있게 감소하였고, TSLP는 각 군 사이에서 의미 있 는 차이가 없었다(Fig. 2).

\section{싸이토카인의 발현과 $\mathrm{IL}-10^{+} \mathrm{B}$ 세포 수 사이의 연관성}

다양한 싸이토카인들의 비용 조직 내 발현 정도와 $\mathrm{IL}^{-10^{+}}$ $\mathrm{B}$ 세포 수 사이의 연관성을 알아보고자 하였다. 그 결과 $\mathrm{BAFF}$ 의 발현과 $\mathrm{IL}-10^{+} \mathrm{B}$ 세포의 수 사이에 양의 상관관계 가 있었지만, 그 외 다른 싸이토카인과 $\mathrm{IL}-10^{+} \mathrm{B}$ 세포 사이 에 아무런 연관성이 없었다(Fig. 3).

Lund-Macay CT score와 IL- $10^{+} \mathrm{B}$ 세포 수 사이의 연관성 CRSwNP 군과 CRSsNP 군 환자를 대상으로 Lund-Macay

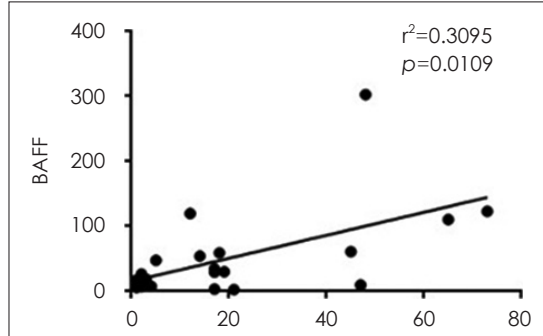

A

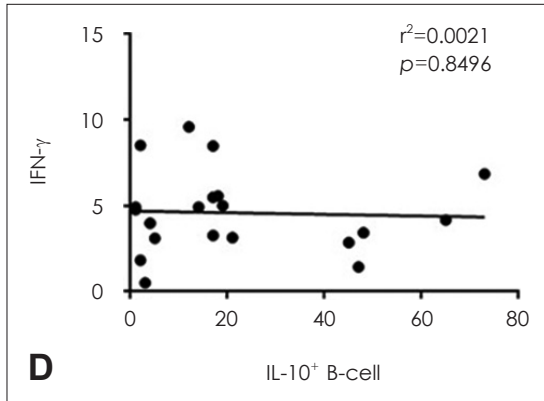

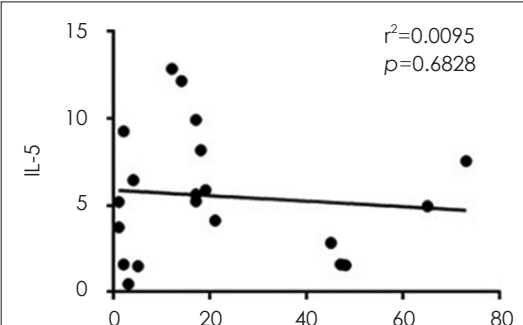

B

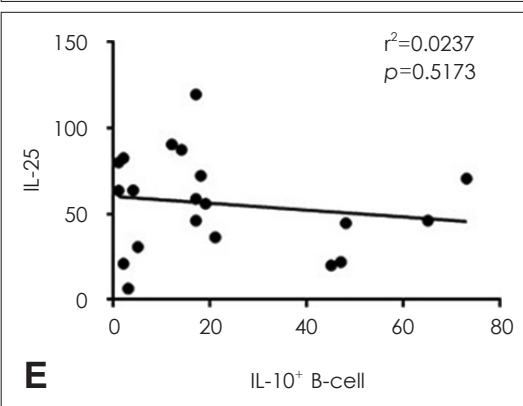

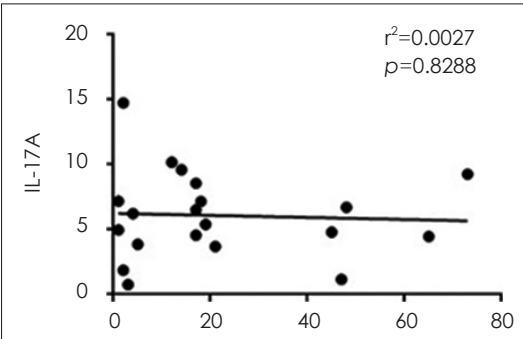

C IL-10+ B-cell

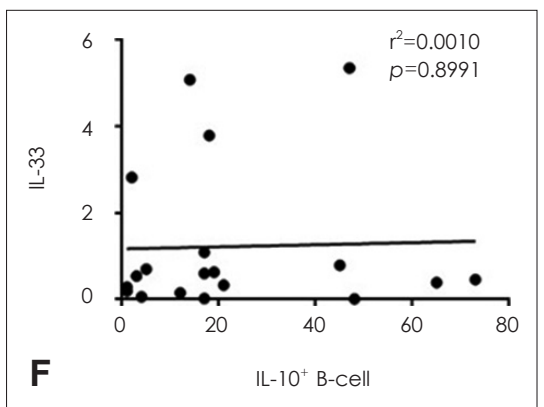

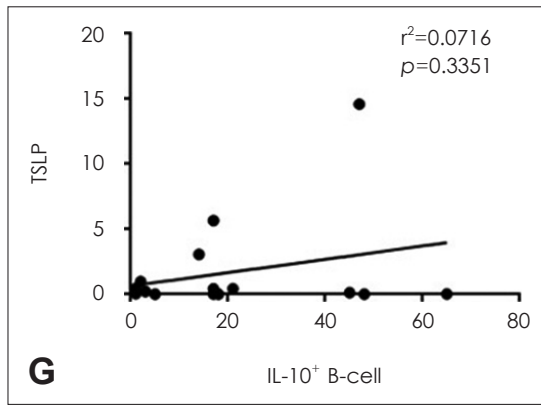

Fig. 3. Relationship of IL-10 $0^{+}$-cell and BAFF (A), IL-5 (B), IL-17A (C), INF-Y (D), IL-25 $(\mathrm{E})$, IL-33 (F), and TSLP (G) expression. BAFF: B cell activating factor, IL: interleukin, INF-y: interferon- $y$, TSLP: thymic stromal lymphopoietin. 


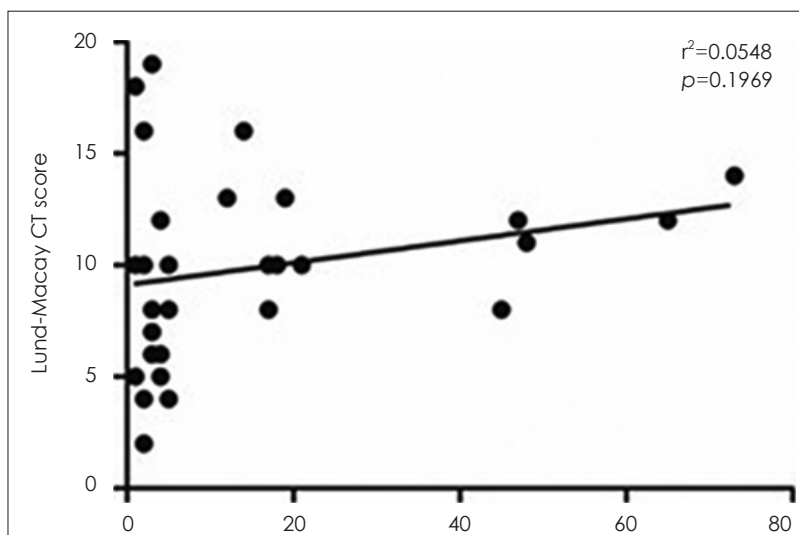

A

IL-10 $10^{+}$B-cells

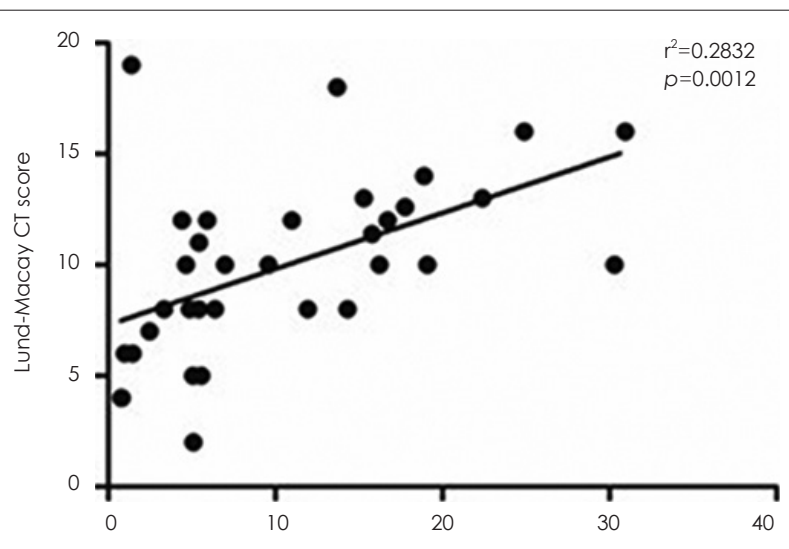

B

Fig. 4. Relationship of Lund-Macay CT score and IL-10 B-cell (A) and expression of IL-10 (B). CT: computed tomography, IL: interleukin.

$\mathrm{CT}$ score와 조직 내 $\mathrm{IL}-10^{+} \mathrm{B}$ 세포 수 사이의 상관관계를 조 사하였다. 그 결과 CT score와 $\mathrm{IL}-10^{+} \mathrm{B}$ 세포 사이에 의미 있 는 상관관계는 보이지 않았다. 하지만, 조직 내 IL-10의 발현 과 Lund-Macay CT score 사이에는 유의한 양의 상관관계 를 보였다(Fig. 4).

\section{고 찰}

CRSwNP 환자의 비용을 호산구성 비용과 비호산구성 비 용으로 구분하려는 시도는 최근 연구들에서 보이는 두드러 진 특징이다. 호산구성 비용은 조직 내 Th2 편향에 의한 호 산구의 침윤, eotaxcin의 발현 증가, 조직의 재형성과 $\mathrm{IL}-5$, IL-13의 발현 증가에 의한 호산구증이 특징이다. 호산구성 비용은 서양인 비용의 특징이며 재발이 흔하고 천식과 같은 질환이 동반되어있는 경우가 더 흔하다.1,18,19) 호산구성 비용 과 비호산구성 비용은 서로 다른 임상적 특징과 수술 후 경 과를 보이는 것으로 알려져 있다. 최근 연구에 따르면 비용 은 호산구뿐만 아니라 $\mathrm{CD}^{+} \mathrm{T}$ cell과 $\mathrm{CD}^{+} \mathrm{T}$ cell이 증가되 어 있으며 효과기 $\mathrm{T}$ 세포와 함께 조절 $\mathrm{T}$ 세포도 증가하는 특 징이 있다. ${ }^{20)}$ 비용을 동반한 만성 비부비동염의 비용은 조직 내 여러 가지 면역세포들과 기질세포들이 다양한 원인에 의해 활성화가 되어 염증반응이 과도하게 일어나는 특징이 있다. 인체 조직 내에서는 과도하게 증폭된 염증반응을 억제하기 위한 기전들이 작동하게 되는데, 조절 $\mathrm{T}$ 세포와 조절 $\mathrm{B}$ 세포 가 이 과정에서 중요한 역할을 한다. 따라서, 조절 $\mathrm{T}$ 세포가 감소하여 여러 문제를 일으키는 자가면역질환과 만성 염증성 질환과는 달리, 비용 조직 내에서는 과도한 염증반응을 억제 하기 위한 기전이 작용하므로 조절 $\mathrm{T}$ 세포의 수와 기능이 비 용에서 증가 되어있는 것은 어찌 보면 당연한 일일 수 있다.

조절 B 세포는 B 세포 중 IL-10을 생성하는 희소한 세포군
으로 최근에 mice와 human에서 발견되었다. 조절 B 세포는 조절 $\mathrm{T}$ 세포처럼 self reactive $\mathrm{CD} 4^{+} \mathrm{T}$ cell을 억제해서 자가 면역질환을 조절하는 것으로 알려져 있다. 하지만 과도하게 그 기능이 활성화되면 감염에 대한 숙주의 대응이 취약해지 고, 종양 면역의 경우 종양의 증식과 원격 전이를 억제하지 못 하는 부작용이 생길 수 있다. ${ }^{21)} \mathrm{Jun} \mathrm{Xu}$ 등은 비용 조직의 PCR 분석을 통해 IL-10 연관 B 세포가 비용을 동반한 만성 비부 비동염환자의 병태생리에 영향을 미친다는 보고를 하였고 이런 결과는 본 연구의 결과와 일치하는 것을 보여주지만, 본 연구에서는 B 세포와 IL-10 항원을 이용한 이중 면역조직형 광염색을 통해 $\mathrm{IL}-10^{+} \mathrm{B}$ 세포의 존재여부를 명확히 하였고 $\mathrm{IL}-10^{+} \mathrm{B}$ 세포와 여러 싸이토카인의 연관성을 밝혀냈다는 것에 의미가 있다.

본 연구에서 저자들은 만성 비부비동염 환자의 점막 및 비용에서의 조절 B 세포의 분포 양상을 알아보고 CRSsNP 군과 대조군의 점막 분포와 비교하고자 하였다. 그 결과 $\mathrm{CRSsNP}$ 환자의 점막 조직에서 CRSwNP 환자의 비용과 대 조군 점막에 비해 $\mathrm{IL}-10^{+} \mathrm{B}$ 세포의 수가 의미 있게 낮음을 알 수 있었는데, CRSsNP의 발병 기전이 조절 B 세포의 기능과 수의 저하로 생겼을 가능성이 있음을 의미한다 할 수 있으며 이전의 연구에서와같이 B 세포의 수와 기능 이상이 천식과 알레르기, 자가면역질환 등에 영향을 미친다는 보고와 일치 하는 측면이 있다고 할 수 있다. ${ }^{10,11)}$

조절 B 세포의 수와 기능 저하로 감염에 대한 숙주의 대 응 면역은 증가하여 있음을 예상할 수 있는데 이에 대한 추 가적인 연구가 필요할 것으로 사료된다.

비용 환자를 호산구성 비용과 비호산구성 환자들로 분류 를 하여 $\mathrm{IL}-10^{+} \mathrm{B}$ 세포의 수를 비교해보았을 때 호산구성 비용은 비호산구성 비용, CRSsNP 군, 대조군에 비해 IL-10 $\mathrm{B}$ 세포의 수가 의미 있게 더 증가하였다. 따라서, 호산구성 
비용에서 과도하게 증폭된 염증반응(특히 Th2 면역반응의 증폭)을 조절하기 위해 조절 $\mathrm{B}$ 세포 역시 수적으로 증가하였 음을 알 수 있다. 다시 증가한 조절 B 세포의 기능으로 인해 비용 조직에서는 감염원(pathogen, 세균 또는 바이러스 등) 에 대한 억제 능력이 감소하고, 효율적으로 제거되지 못한 이 들 pathogen에 의해 염증이 다시 증폭되는 악순환이 일어난 다고 할 수 있다. 본 연구는 면역형광염색에 의한 형태학적인 관찰 연구로 호산구성 비용에서 조절 B 세포의 수가 증가하 는 현상에 대해서는 추후 추가적인 분자생물학적 연구와 조 절 B 세포에 대한 기능적인 연구가 필요할 것으로 사료된다.

본 연구에서는 비용 조직에서 다양하게 발현되는 것으로 알려진 싸이토카인들을 함께 측정하여 $\mathrm{IL}-10^{+} \mathrm{B}$ 세포의 수 와 연관성이 있는지 알아보고자 하였는데, 유일하게 BAFF 와 의미 있는 양의 상관관계를 보였다. BAFF는 B 세포와 형 질세포에 특이적으로 발현되어있는 $\mathrm{BAFF}$ 의 수용체에 결합 하여 $\mathrm{B}$ 세포뿐만 아니라 조절 $\mathrm{B}$ 세포의 증식과 활성화를 조 절하는 것으로 알려져 있다. ${ }^{22,23)}$ 따라서, $\mathrm{BAFF}$ 와 $\mathrm{IL}^{-1} 0^{+} \mathrm{B}$ 세포의 수 사이에 연관성이 있는 것은 예측 가능한 결과였다. $\mathrm{BAFF}$ 는 조절 $\mathrm{B}$ 세포 뿐만 아니라 다른 $\mathrm{B}$ 세포와 형질 세포 를 활성화시키므로 $\mathrm{BAFF}$ 를 타깃으로 하여 $\mathrm{BAFF}$ 의 기능 을 억제하는 치료제가 개발된다면 조절 B 세포의 기능을 억 제하여 조직 내 감염원을 줄이고 활성화된 B 세포 또한 억제 하여 조직 내 염증반응도 감소시킬 수 있을 것으로 추정되며, 이에 대한 in vivo 연구가 추후에 필요할 것으로 생각한다.

본 연구에서는 조직에서 비용의 발생에 관련이 있는 Th1, $\mathrm{Th} 2$, Th17, innate 싸이토카인 중에 각각 대표적인 싸이토카 인인 IFN- $\gamma$, IL-5, IL-17A, IL-25, IL-33, TSLP의 mRNA 발현을 측정하였다. 하지만, $\mathrm{BAFF}$ 와 다르게 $\mathrm{IL}-10^{+} \mathrm{B}$ 세포 의 수와 의미 있는 상관관계를 보이는 싸이토카인은 없었다. IFN- $\gamma, \mathrm{IL}-5, \mathrm{IL}-17 \mathrm{~A}$ 는 대조군에 비해 염증 조직(CRSsNP, CRSwNP)에서 의미 있는 발현 증가를 보였지만 phenotype 에 따른 의미 있는 발현 차이를 보이지 않아서 본 연구의 대 상군에서는 병태생리에서 중요한 역할을 한다고 볼 수 없었 다. 선천성 싸이토카인은 Th 싸이토카인과 다른 발현 양상 을 보였는데, 특히 IL-25이 비용 조직에서 다른 조직에 비해 강한 발현을 보여 비용의 발생 기전에 중요한 역할을 할 것으 로 추정하였다. IL-25의 발현 증가는 동양인의 비용에서 그 발현이 뚜렷하게 증가함을 이전의 연구에서도 알 수 있다.)

조절 $\mathrm{B}$ 세포의 수가 증가하고 그 기능이 강할수록 감염원 의 증가와 염증의 증폭으로 질환의 심각도와 질환이 범위가 증가할 것으로 추정된다. 만성 비부비동염에서 질환의 심각 도와 범위를 평가할 때 Lund-Macay CT score를 흔히 사용 한다. ${ }^{24)}$ 본 연구에서 $\mathrm{IL}-10 \mathrm{mRNA}$ 발현 및 $\mathrm{IL}-10^{+} \mathrm{B}$ 세포의
수와 Lund-Macay CT score와의 연관성을 조사하였는데, IL-10 발현 정도와 Lund-Macay CT score와는 유의한 양의 상관관계를 보였으나 $\mathrm{IL}-10^{+} \mathrm{B}$ 세포 수와는 유의한 상관관계 를 보이지 않았다. 하지만, fluorescence-activated cell sort$\operatorname{ing}(\mathrm{FACS})$ 와 같은 보다 더 정량적인 방법으로 조절 $\mathrm{B}$ 세포 수를 측정할 경우에는 IL-10의 발현과 비슷한 결과를 보이 지 않을까 생각한다.

조직 내 조절 $\mathrm{B}$ 세포의 증가로 인한 감염원의 조절 실패와 염증반응의 악화로 호산구성 비용이 발병할 것으로 추정되 며 이 과정에 $\mathrm{BAFF}$ 가 중요한 매개 인자로 작용할 가능성이 있을 것으로 생각된다. 이에 대한 추가적인 연구가 향후 필요 할 것으로 생각된다.

결론적으로, $\mathrm{CRSwNP}$ 환자의 비용 조직에서 $\mathrm{CRSsNP}$ 환 자와 대조군의 점막 조직에 비해 $\mathrm{IL}-10^{+} \mathrm{B}$ 세포와 $\mathrm{BAFF}$ 의 발현이 의미 있게 증가하였으며, 특히 $\mathrm{IL}_{-10^{+}} \mathrm{B}$ 세포는 호산 구성 비용 조직에서 더욱더 의미 있게 증가하였다. 이러한 결 과는 조절 B 세포가 호산구성 비용의 병태생리에 관여함을 의미하며 $\mathrm{BAFF}$ 은 조절 $\mathrm{B}$ 세포의 생성에 기여함을 의미한 다. $\mathrm{BAFF}$ 가 조절 $\mathrm{B}$ 세포의 생성에 기여하는 기전과 조절 $\mathrm{B}$ 세포가 비용 형성에 미치는 영향에 대한 기전을 규명할 수 있는 병태생리학적 연구가 추가적으로 필요할 것으로 생각 한다. 이러한 연구는 잦은 재발과 악화로 예후가 불량한 $\mathrm{CRSwNP}$ 환자의 치료에 도움이 될 것으로 생각한다.

\section{REFERENCES}

1) Taylor MJ, Ponikau JU, Sherris DA, Kern EB, Gaffey TA, Kephart $\mathrm{G}$, et al. Detection of fungal organisms in eosinophilic mucin using a fluorescin-labelled chitin specific binding protein. Otolaryngol Head Neck Surg 2002;127(5):377-83.

2) Bachert C, Gevaert P, van Cauwenberge P. Staphylococcus aureus superantigens and airway disease. Curr Allergy Asthma Rep 2002; 2(3):252-8.

3) Zhang N, Van Zele T, Perez-Novo C, Van Bruaene N, Holtappels G, DeRuyck N, et al. Different types of T-effector cells orchestrate mucosal inflammation in chronic sinus disease. J Allergy Clin Immunol 2008;122(5):961-8.

4) Fokkens W, Lund V, Mullol J; European Position Paper on Rhinosinusitis and Nasal Polyps group. European position paper on rhinosinusitis and nasal polyps 2007. Rhinol Suppl 2007;20:1-136.

5) Sharma S, Watanabe S, Sivam A, Wang J, Neuwirth SJ, Perez RI, et al. Peripheral blood and tissue $\mathrm{T}$ regulatory cells in chronic rhinosinusitis. Am J Rhinol Allergy 2012;26(5):371-9.

6) Shen Y, Tang XY, Yang YC, Ke X, Kou W, Pan CK, et al. Impaired balance of Th17/Treg in patients with nasal polyposis. Scand J Immunol 2011;74(2):176-85.

7) Xu J, Han R, Kim DW, Mo JH, Jin Y, Rha KS, et al. Role of interleukin-10 on nasal polypogenesis in patients with chronic rhinosinusitis with nasal polyps. PLoS One 2016;11(9):e0161013.

8) Kapasi ZF, Burton GF, Shultz LD, Tew JG, Szakal AK. Induction of functional follicular dendritic cell development in severe combined immunodeficiency mice: influence B and T cells. J Immunol 1993; 150(7):2648-58. 
9) Yoshida K, van den Berg TK, Dijkstra CD. The functional state of follicular dendritic cells in severe combined immunodeficient (SCID) mice: role of the lymphocytes. Eur J Immunol 1994;24(2): 464-8.

10) Lee JS, Kwon BS, Cho HR. Prevention of allograft rejection by immune tolerance. J Korean Soc Transplant 2006;20(1):1-13.

11) Sin E, Anand P, Frieri M. A link: allergic rhinitis, asthma \& systemic lupus erythematosus. Autoimmun Rev 2016;15(5):487-91.

12) Noh G, Lee JH. Regulatory B cells and allergic diseases. Allergy Asthma Immunol Res 2011;3(3):168-77.

13) Driscoll KE, Carter JM, Howard BW, Hassenbein D, Burdick M, Kunkel SL, et al. Interleukin-10 regulates quartz-induced pulmonary inflammation in rats. Am J Physiol 1998;275(5 Pt 1):L887-94.

14) Kühn R, Löhler J, Rennick D, Rajewsky K, Müller W. Interleukin10-deficient mice develop chronic enterocolitis. Cell 1993;75(2): 263-74.

15) Braat H, Peppelenbosch MP, Hommes DW. Immunology of Crohn's disease. Ann N Y Acad Sci 2006;1072:135-54.

16) Lee JH, Byun JA, Yeo SW, Kim JK, Park YS. Role of interleukin-10 on mouse otitis media model using lipopolysaccharide. Korean J Otorhinolaryngol-Head Neck Surg 2011;54(1):43-7.

17) Fokkens WJ, Lund VJ, Mullol J, Bachert C, Alobid I, Baroody F, et al, European position paper on rhinosinusitis and nasal polyps
2012. Rhinol Suppl 2012;23:1-298.

18) Kim JW, Hong SL, Kim YK, Lee CH, Min YG, Rhee CS. Histological and immunological features of noneosinophilic nasal polyps. Otolaryngol Head Neck Surg 2007;137(6):925-30.

19) Kang JM, Kim SW, Auo HJ, Park CS, Kim BG, Kim SW, et al. [Clinical significance of serum eosinophil cationic protein (ECP) in chronic rhinosinusitis with nasal polyposis]. Korean J OtorhinolaryngolHead Neck Surg 2008;51(8):712-6.

20) Ickrath P, Kleinsasser N, Ding X, Ginzkey C, Beyersdorf N, Hagen R, et al. Characterization of T-cell subpopulations in patients with chronic rhinosinusitis with nasal polyposis. Allergy Rhinol (Providence) 2017;8(3):139-47.

21) Liu J, Zhan W, Kim CJ, Clayton K, Zhao H, Lee E, et al. IL-10producing $\mathrm{B}$ cells are induced early in HIV-1 infection and suppress HIV-1-specific T cell responses. PLoS One 2014;9(2):e89236.

22) Schneider P, MacKay F, Steiner V, Hofmann K, Bodmer JL, Holler $\mathrm{N}$, et al. BAFF, a novel ligand of the tumor necrosis factor family, stimulates B cell growth. J Exp Med 1999;189(11):1747-56.

23) Bossen C, Schneider P. BAFF, APRIL and their receptors: structure, function and signaling. Semin Immunol 2006;18(5):263-75.

24) Hopkins C, Browne JP, Slack R, Lund V, Brown P. The Lund-Mackay staging system for chronic rhinosinusitis: how is it used and what does it predict? Otolaryngol Head Neck Surg 2007;137(4):555-61. 